\section{The relationship between Innovation and Global Competitiveness: The mediating role of Management Practices evaluated by Structural Equation Modeling}

\author{
Paulo Roberto Feldmann ${ }^{1}$ \\ ${ }^{1}$ USP - Universidade de São Paulo - Programa de Pós-Graduação \\ em Administração/Faculdade de Economia, Administração e \\ Contabilidade - PPGA/FEA - São Paulo - Brazil \\ Rafael Ricardo Jacomossi ${ }^{2}$ \\ ${ }^{2}$ Centro Universitário FEI - São Paulo - Brazil \\ Alcides Barrichello ${ }^{3}$ \\ ${ }^{3}$ Universidade Presbiteriana Mackenzie - \\ Pós-Graduação Lato Sensu - São Paulo - Brazil

\section{Rogério Scabim Morano ${ }^{4}$} \\ ${ }^{4}$ UNIFESP - Universidade Federal de São Paulo - \\ Departamento de Engenharia Química - Diadema - Brazil
}

\begin{abstract}
Purpose - This study seeks to investigate whether a good management environment in companies determines results in terms of country competitiveness. Additionally, it aims to verify if innovation plays a role in contributing to this.
\end{abstract}

Design/methodology/approach - The study used structural equation modeling and data on 138 countries contemplated in The Global Competitiveness Report 2016/2017 (2016 World Economic Forum). A number of theories have been used to relate competitiveness to innovation and to management practices. This discussion was expanded, taking these variables into account in a more comprehensive framework.

Findings - The analysis performed indicates the role of best management practices as a mediator in the relationship that exists between innovation and global competitiveness, which reinforces the importance of a good level of management

Originality/Value- There have been many studies and discussions about global competitiveness. The factors in the literature used to explain a country's degree of competitiveness include cheap labor, abundant raw materials, the amount of capital available for investment, and, especially, the capacity to innovate. Some authors point to a fifth
Received on

$12 / 01 / 2017$

Approved on

$11 / 30 / 2018$

Responsible editor:

Prof. Dr. João Mauricio Gama

Evaluation process:

Double Blind Review

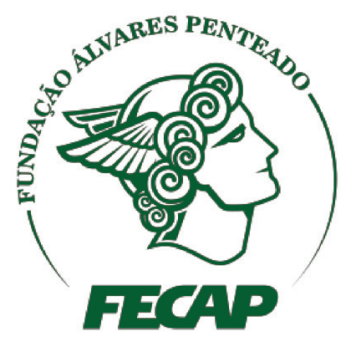

Review of Business Management

DOI:10.7819/rbgn.v21i2.3970 
factor: best management practices. The paper shows how this factor improves competitiveness. The most important contribution of this study is to demonstrate that innovation alone cannot by itself ensure competitiveness in companies or nations, and requires the simultaneous presence of best management practices.

Keywords- Global competitiveness; Innovation; Best management practices; Structural equation modeling.

\section{Introduction}

From the perspective of economic theory, dating back to Adam Smith, the explanation for the development of nations has been viewed as being due to a combination of factors of production: cheap labor, abundant raw materials, and the availability of investment capital. A fourth variable was later added to this list: the ability to innovate. The current economic competitiveness paradigm is based on the ability of countries and their respective companies to innovate (Ichijo \& Nonaka, 2007; Nelson \& Winter, 1982; Schumpeter, 1934).

Porter (1990) postulated that it is not nations that are powerful, but rather the companies that operate within their territories. Therefore, in the context of the development of nations, every two years the World Economic Forum (Schwab, Sala-i-Martín, Samans, \& Blanke, 2016) publishes a global competitiveness ranking which evaluates roughly 150 countries.

This ranking combines 114 indicators grouped into 12 pillars that capture concepts that matter for productivity and long-term prosperity: Institutions, Infrastructure, Macroeconomic environment, Health and primary education, Higher education and training, Goods market efficiency, Labor market efficiency, Financial market development, Technological readiness, Market size, Business sophistication, and Innovation. The ranking is based on successive aggregations of scores from the indicator level using a specific weighting process. The indicators come from statistical data from internationally recognized organizations and other aspects derived from the World Economic Forum's Executive Opinion Survey are also included.

It is notable that the most developed countries appear in the top positions of this ranking: Switzerland appears in $1^{\text {st }}$ position, Singapore in $2^{\text {nd }}$, followed by the United States in $3^{\text {rd }}$, the Netherlands in $4^{\text {th }}$, and Germany in $5^{\text {th }}$. Even though the global competitiveness ranking is constructed based on various pillars, innovation plays an important part.

Some explanations for a lack of global competitiveness are related to low levels of innovation, more specifically low levels of research and development (R\&D) investment (Aoki, 1991; Greve, 2003; Hall, Lotti, \& Mairesse, 2013; Ichijo \& Nonaka, 2007). While various studies point to the importance of the existence of an innovation process to increase global competitiveness, global competitiveness in turn is dependent on how productive a nation and/or an organization is (Porter, 1990).

The effects of $\mathrm{R} \& \mathrm{D}$ spending on productivity are due to innovation and its incorporation into the production process (Griliches, 1979; Khan, Salim, Bloch, \& Islam, 2017; Mairesse \& Robin, 2009; Medda \& Piga, 2014; Parisi, Schiantarelli, \& Sembenelli, 2006; Wakelin, 2001; Zhang et al., 2011). On the other hand, other studies indicate that gains in productivity and, as a consequence, increases in global competitiveness are not solely related to the efforts made to innovate (Carvalho \& Avellar, 2013; Cavalcante \& de Negri, 2014; Goedhuys, 2007; Rogers, 2006; Steingraber, 2009). Other factors have also been identified to explain this relationship, such as organizational change, personnel development, cooperation, and the acquisition of machines and equipment, among others. However, for Agarwal, Brown, Green, Randhawa, and Tan (2014), Bloom and Van Reenen (2006, 2007, 2010), and Mundlak (1961), some patterns observed in certain countries, such as investment in innovation resulting in increases in productivity, 
are not observed in all nations. Even though it is hypothesized that these differences in productivity are due to technological innovations represented by patents or adaptations to new machines, there is another explanation for these variations, which is that they are the result of management practices. Thus, this possibility of relating best management practices, innovation, and global competitiveness represents quite an important theoretical theme to be investigated, where best management practices are those practices that lead to better company performance in a wide variety of economic sectors.

The abovementioned idea raises the following research problem: what is the effect of the adoption of best management practices in terms of the relationship between innovation and global competitiveness?

This study seeks to use structural equation modeling to investigate whether best management practices represent a determinant factor in a nation's attempt to become competitive and it will endeavor to understand the role of innovation within this context. To do this, this article is divided into sections, starting with a literature review, followed by details of the methodology, then a presentation and analysis of the results obtained, and, finally, the conclusions.

\section{Review of the Literature}

This section will deal with three pillars that provide theoretical support to this study: the first deals with the relationship between innovation in the corporate environment and its effects on global competitiveness, and the second one addresses the relationship between best management practices and their effects on global competitiveness. The third one presents some thoughts about the relationship between these variables all together.

\section{a) The relationship between innovation in the corporate environment and its effects on global competitiveness}

Innovation is important in driving economic progress and global competitiveness in developed as well as developing nations, and many governments therefore place it at the center of their growth strategies. The recognition and celebration of innovation in emerging markets is also something that can inspire people, especially the next generation of managers and entrepreneurs (Drejer, 2002; Dutta, Lanvin, \& Wunsch-Vincent, 2016).

Studies of the performance of firms and nations point to the role of technological innovation as an important explanation for growth in global competitiveness, and as a result, the production of material wealth (Nelson \& Winter, 1982; Pavitt, 1984; Rosenberg, 1982; Schumpeter, 1934). In recent years, the traditional innovation literature has delved further into various studies related to the development of organizational abilities that help firms in this aspect in response to the challenges imposed by ever more turbulent market scenarios (Crossan \& Apaydin, 2010; K. Ichijo \& Nonaka, 2007; Panayides, 2006). The role of organizations is extremely important in this process, because they have the capacity to transform their realities in accordance with the information that they receive from their environment, and can thus act as agents for the transfer and diffusion of innovation and new technologies. Organizational and microeconomic studies have been designed to investigate the importance of the role of innovation in improving company performance. Porter (1990) analyzes competition in various sectors of the economy in a variety of countries and infers that successful companies are the ones that best know how to use technology and are the most efficient in launching innovations. Based on this aspect, the author infers that how advanced and developed countries are depends on how much they can create business environments which can innovate more rapidly than their foreign rivals. He addresses the theme of innovation and its relationship with performance in relation to various factors.

Organizational and microeconomic studies have been designed to investigate the importance of the role of innovation in improving 
company performance. Porter (1990) analyzes competition in various sectors of the economy in a variety of countries and infers that successful companies are the ones that best know how to use technology and are the most efficient in launching innovations. Based on this aspect, the author infers that how advanced and developed countries are depends on how much they can create business environments which can innovate more rapidly than their foreign rivals. He addresses the theme of innovation and its relationship with performance in relation to various factors.

One of these, called absorptive capacity, concerns the way firms absorb outside knowledge and adopt it in their processes, transforming their structure, and thus gaining innovative products as inputs, with results that increase their global competitiveness (Armstrong \& Lengnick-Hall, 2013; Brettel, Greve, \& Flatten, 2011; Cohen \& Levinthal, 1990; Najafi-Tavani, Sharifi, \& S. Ismail, 2014; Ritala \& Hurmelinna-Laukkanen, 2013; Zahra \& George, 2002). Other studies relate the importance of the role of $R \& D$ investment to the diffusion of innovations (Bae, 2016; Bertrand \& Mol, 2013; Kim, 2015), associating this with improved performance. A third group of studies (Blomstrom, 1986; Blomstrom \& Kokko, 1998; Liu, 2008; Suyanto, Bloch, \& Salim, 2012; Suyanto \& Salim, 2013) relates the role of foreign multinationals and local subsidiaries in the generation of knowledge transfers to the country which receives these new technologies, which thus increases the country's productivity and provides it with greater competitiveness in relation to other nations.

More recently, an analysis was published regarding the growth of the American economy over the last 140 years (Gordon, 2016). This study not only found that growth was directly related to the generation of innovations, but also that the productivity of the United States reached its zenith during the period between 1940 and 1970 due to the surge in the number of discoveries and innovations during these decades.
Additionally, other authors suggest that innovation is one of the main components for organizational success. It is fundamental for an organization to remain competitive, thus developing and protecting its market share against the competition. It is the consequence of several elements such as knowledge management, intellectual capital, organizational culture, and organizational capacities. One of these capacities is the management skills of the organization (Chatzoglou \& Chatzoudes, 2017).

\section{b) The relationship between best management practices and their effects on global competitiveness}

Global competitiveness studies are extremely relevant to the areas of administration and economics, because a nation becomes more competitive only by improving its productivity indices (Gordon, 2016; Lederman, Messina, Pienknagura, \& Rigolini, 2014; Nagano, Stefanovitz, \& Vick, 2014; Porter, 1990; Teixeira $\&$ dos Santos, 2016).

Early studies on this subject have demonstrated that the traditional efficient combination of capital and labor could not even account for ten percent of the growth in advanced economies, nor related the difference to increases in productivity (Abramovitz, 1950; Solow, 1956). This growth is also due to the degree of technological change represented by innovations (Nelson \& Winter, 1982). Other explanations have come to light, such as technological level, the size of firms, the origin of capital, the sector that they operate in, and the level of labor specialization (Mazzucato, 2015).

Despite the hypothesis that these differences in productivity are due to technological innovations represented by patents or adaptations to new machines, there is another explanation for them, which is that they are due to management practices (Agarwal et al., 2014; Bloom \& Van Reenen, 2006, 2007, 2010; Mundlak, 1961). Bloom and Van Reenen (2006, 2007, 2010) note 
that economists do not focus on investigating management practices because of the difficulty in measuring this construct due to its subjectivity. Despite the controversy in terms of what constitutes best management practices, studies have shown that adopting certain practices has led to improved company performance in a wide variety of economic sectors (Alexopoulos \& Tombe, 2009; Cua, Mckone, \& Schroeder, 2001; De Cerio, 2003; Hsu, Tan, Kannan, \& Leong, 2009; Sadikoglu \& Zehir, 2010).Analyzing industrial sectors, it is concluded that management practices should be adjusted to the competitive advantages of each sector in each country. Thus, in this aspect the form of management in each country is strongly influenced by local culture (Porter, 1990).

Relevant studies in this area identify management standards. These studies created and perfected an instrument, the so-called Best Management Practices (BMP), to measure the quality of organizational management. They initially applied it to 732 manufacturers in the USA, France, Germany, and the United Kingdom, and later they applied it to almost 6,000 companies located in a variety of countries. The results indicated that the management practices adopted by firms strongly correlate with levels of productivity and profitability. These studies also showed that deficient management practices tend to be found in sectors with weak competition or in companies which usually pass on the management of the company to the eldest children of the owners (Bloom \& Van Reenen, 2006, 2007, 2010).

\section{c) The relationship between innovation, global competitiveness, and best management practices}

Some authors relate best management practices to innovation (Lederman et al., 2014; Lerner \& Azoulay, 2012; Porter, 1990). Lederman et al. (2014), for example, mention that the reason why Latin American companies grow so slowly is related to the lack of innovation. The authors add that Latin American companies are far from applying global best management practices and their investment in $\mathrm{R} \& \mathrm{D}$ is low, which implies that patent activity is well below benchmark levels. When analyzing why local management practices are so important to the development of nations, Porter (1990) emphasizes that these practices are responsible for the improvement of firms and needed to increase their capacity for innovation. Other studies relating management practices and capacity of innovation have been presented since then (Christensen, 2006; Christensen \& Raynor, 2013).

In turn, Lerner and Azoulay (2012) point out that when analyzing the various aspects of organizational structure that affect the production of innovation, many interfaces were found. The fact is that there is not a very well-developed literature that relates all three elements together: innovation, global competitiveness, and best management practices.

This was understood as a potential gap which could be filled by the present study. Thus, some conceptual models were elaborated with different causal relationships between these variables to determine which of them has the greatest significance and could therefore be most adequate for representing such interactions. Details of this process are presented in the methodology chapter.

\section{Methodology}

This study used secondary data from indicators presented in The Global Competitiveness Report (GCR) 2016-2017 (Schwab et al., 2016), which contains data on 138 countries. This number of countries and their distribution in regions compose the entire universe surveyed by the GCR, as presented in Table 1 . 
Table 1

Countries / regions from GCR database

\begin{tabular}{|c|c|c|c|c|c|}
\hline Region & Country & Region & Country & Region & Country \\
\hline \multirow{17}{*}{ 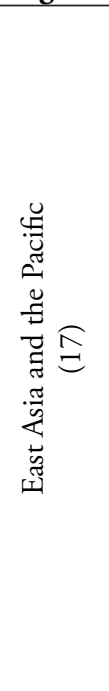 } & Australia & \multirow{37}{*}{ 苂 } & Albania & \multirow{31}{*}{ 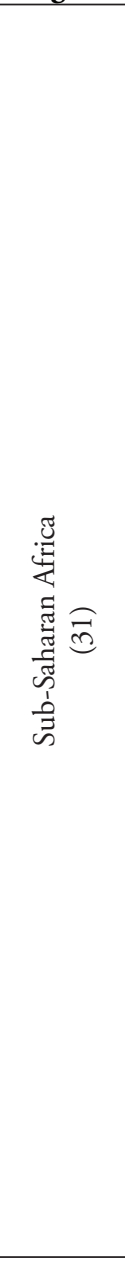 } & Benin \\
\hline & Brunei Darussalam & & Austria & & Botswana \\
\hline & Cambodia & & Belgium & & Burundi \\
\hline & China & & Bosnia & & Cameroon \\
\hline & Hong Kong SAR & & Bulgaria & & Cape Verde \\
\hline & Indonesia & & Croatia & & Chad \\
\hline & Japan & & Cyprus & & Congo, D. Rep. \\
\hline & Korea, Rep. & & Czech Republic & & Côte d'Ivoire \\
\hline & Lao PDR & & $\begin{array}{l}\text { Denmark } \\
\text { Den }\end{array}$ & & Ethiopia \\
\hline & Malaysia & & Estonia & & Gabon \\
\hline & Mongolia & & Finland & & Gambia, The \\
\hline & New Zealand & & France & & Ghana \\
\hline & Philippines & & Germany & & Kenya \\
\hline & Singapore & & Greece & & Lesotho \\
\hline & Taiwan, China & & Hungary & & Liberia \\
\hline & Thailand & & Iceland & & Madagascar \\
\hline & Vietnam & & Ireland & & Malawi \\
\hline \multirow{9}{*}{ 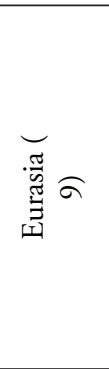 } & Armenia & & Italy & & Mali \\
\hline & Azerbaijan & & Latvia & & Mauritania \\
\hline & Georgia & & Lithuania & & Mauritius \\
\hline & Kazakhstan & & Luxembourg & & Mozambique \\
\hline & Kyrgyz Republic & & Macedonia, FYR & & Namibia \\
\hline & Moldova & & Malta & & Nigeria \\
\hline & Russian Federation & & Montenegro & & Rwanda \\
\hline & Tajikistan & & Netherlands & & Senegal \\
\hline & Ukraine & & Norway & & Sierra Leone \\
\hline \multirow{26}{*}{ 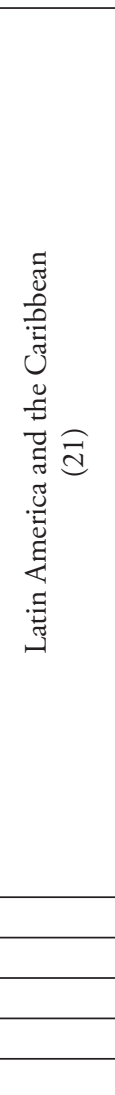 } & Argentina & & Poland & & South Africa \\
\hline & Barbados & & Portugal & & Tanzania \\
\hline & Bolivia & & Romania & & Uganda \\
\hline & Brazil & & Serbia & & Zambia \\
\hline & Chile & & Slovak Republic & & Zimbabwe \\
\hline & Colombia & & Slovenia & \multirow{8}{*}{$\begin{array}{l}\frac{\pi}{3} \\
\frac{1}{4} \\
\frac{1}{ \pm} \\
0 \\
0\end{array}$} & Canada \\
\hline & Costa Rica & & Spain & & United States \\
\hline & Dominican Republic & & Sweden & & Bangladesh \\
\hline & Ecuador & & Switzerland & & Bhutan \\
\hline & El Salvador & & Turkey & & India \\
\hline & Guatemala & & United Kingdom & & Nepal \\
\hline & Honduras & \multirow{15}{*}{ 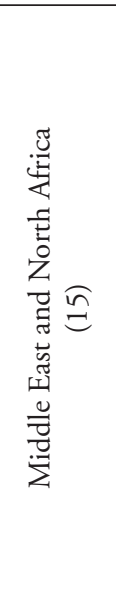 } & Algeria & & Pakistan \\
\hline & Jamaica & & Bahrain & & Sri Lanka \\
\hline & Mexico & & Egypt & & \\
\hline & Nicaragua & & Iran, Islamic Rep. & & \\
\hline & Panama & & Israel & & \\
\hline & Paraguay & & Jordan & & \\
\hline & Peru & & Kuwait & & \\
\hline & Trinidad and Tobago & & Lebanon & & \\
\hline & Uruguay & & Morocco & & \\
\hline & Venezuela & & Oman & & \\
\hline & & & Qatar & & \\
\hline & & & Saudi Arabia & & \\
\hline & & & Tunisia & & \\
\hline & & & United Arab Emirates & & \\
\hline & & & Yemen & & \\
\hline
\end{tabular}

Source: Adapted from Schwab et al. (2016) 
The objective of this paper is to measure the impact of management practices on the relationship between innovation and global competitiveness; therefore it first sought to identify among the GCR's items those that best represent corporate management practices in various countries. It should be noted that the level of analysis used by the GCR is country. Thus, all indicators presented in the report follow this pattern, including the indicators that address the characteristics of the companies. The GCR does not present the specific indicators of each company and the type of industry, but rather general data aggregated by country.

The GCR contemplates three dimensions which make up its global competitiveness index. These dimensions are divided into twelve pillars, from which items were identified to compose this study. Among the existing indicators in the GCR, those that report aspects related to management practices were identified (Rao, Solis, \& Raghunathan, 1999). From the fifth pillar (Higher education and training), the Quality of Management Schools variable was extracted; from the sixth pillar (Goods market efficiency), the Buyer Sophistication variable was used; from the seventh pillar (Labor market efficiency), Cooperation in Labor-Employer Relations, Hiring and Firing Practices, Pay and Productivity, and Reliance on Professional Management were selected; from the ninth pillar (Technological readiness), the variables Firm Level Technology Absorption, and Firm Direct Investment (FDI) and Technology Transfer were captured; from the eleventh pillar (Business sophistication), the variables Local Supplier Quantity, Local Supplier Quality, Production Process Sophistication, and Willingness to Delegate Authority were extracted. In addition, the items within the twelfth pillar (Innovation) and the Global Competitiveness Index itself were used to characterize the other variables utilized in this study.

Table 2 presents the definitions of the variables used to compose the Management Practices construct. These definitions were extracted from the GCR and are in line with the constructs from Rao, Solis, and Raghunathan (1999).

Table 2

\section{Conceptual definitions of variables used}

\begin{tabular}{ll}
\hline Variable & Definition \\
\hline Quality of management schools & In the country, the assessment made of the quality of management schools. \\
\hline Buyer sophistication & In the country, on what basis the purchasing decisions are made by the buyers. \\
\hline Cooperation in labor-employer relations & In the country, how labor-employer relations are characterized. \\
\hline Hiring and firing practices & In the country, to what extent regulations allow flexible hiring and firing of workers. \\
\hline Pay and productivity & In the country, to what extent pay is related to employee productivity. \\
\hline Reliance on professional management & In the country, who holds senior management positions in companies. \\
\hline Firm level technology absorption & In the country, to what extent businesses adopt the latest technologies. \\
\hline FDI and technology transfer & To what extent foreign direct investment (FDI) brings new technology into the country. \\
\hline Local supplier quantity & In the country, how numerous are local suppliers. \\
\hline Production process sophistication & In the country, the assessment made of the quality of local suppliers. \\
\hline Willingness to delegate authority & In the country, how sophisticated production processes are. \\
\hline Global Competitiveness & In the country, the assessment made of the willingness to delegate authority to subordinates. \\
\hline Innovation & $\begin{array}{l}\text { Set of institutions, policies, and factors that determine the level of productivity of an economy, } \\
\text { which in turn sets the level of prosperity that the country can achieve. }\end{array}$ \\
$\begin{array}{l}\text { Sufficient investment in research and development (R\&D), especially by the private sector; the } \\
\text { presence of high-quality scientific research institutions that can generate the basic knowledge } \\
\text { needed to build new technologies; extensive collaboration in research and technological } \\
\text { developments between universities and industry; and the protection of intellectual property. }\end{array}$ \\
\hline
\end{tabular}

Source: Adapted from Schwab et al. (2016) 
Based on previous studies that deal with innovation and its effects on global competitiveness (Nelson \& Winter, 1982; Pavitt, 1984; Porter, 1990; Rosenberg, 1982; Schumpeter, 1934), Model 1 was conceived, which relates these two variables directly. According to Bloom and Van Reenen (2006, 2007, 2010), Best Management Practices are also associated with Global Competitiveness, which led to the creation of Model 2. Figure 1 presents these models.

Model 1

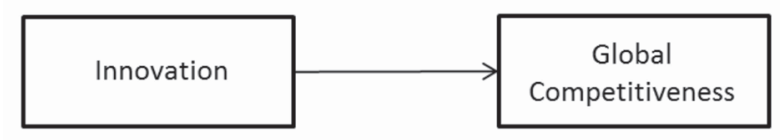

Model 2

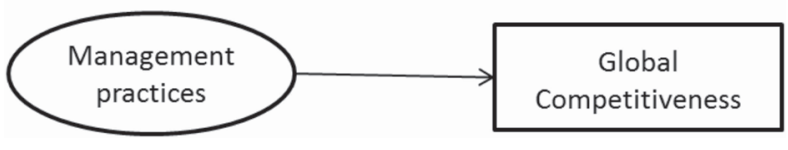

Figure 1 - Basic models

Source: Authors

As mentioned before, Lederman et al. (2014), Lerner and Azoulay (2012), and Porter (1990) relate only Best Management Practice to Innovation. This being so, it was decided to elaborate theoretical Models 3, 4, and 5, which unite the three variables simultaneously. The Management Practices variable is made up of 12 GCR indicators as explained above which are understood to be part of the concept of best management practices.

The three models (Figure 2) were created so that the Management Practices variable is an antecedent of Innovation (Model 3), a mediator between Innovation and Global Competitiveness (Model 4), and a competitor of Innovation (Model 5). This was done to verify which relationship between the three variables is most appropriate.

The Management Practices variable is a latent one (Byrne, 2010) and thus it was subjected to confirmatory factor analysis. The number of countries in the database was greater than the minimum value needed to relate five rows per item, which ensures that the data is significant and the sample representative for the data used with this variable (Bentler \& Chou, 1987).
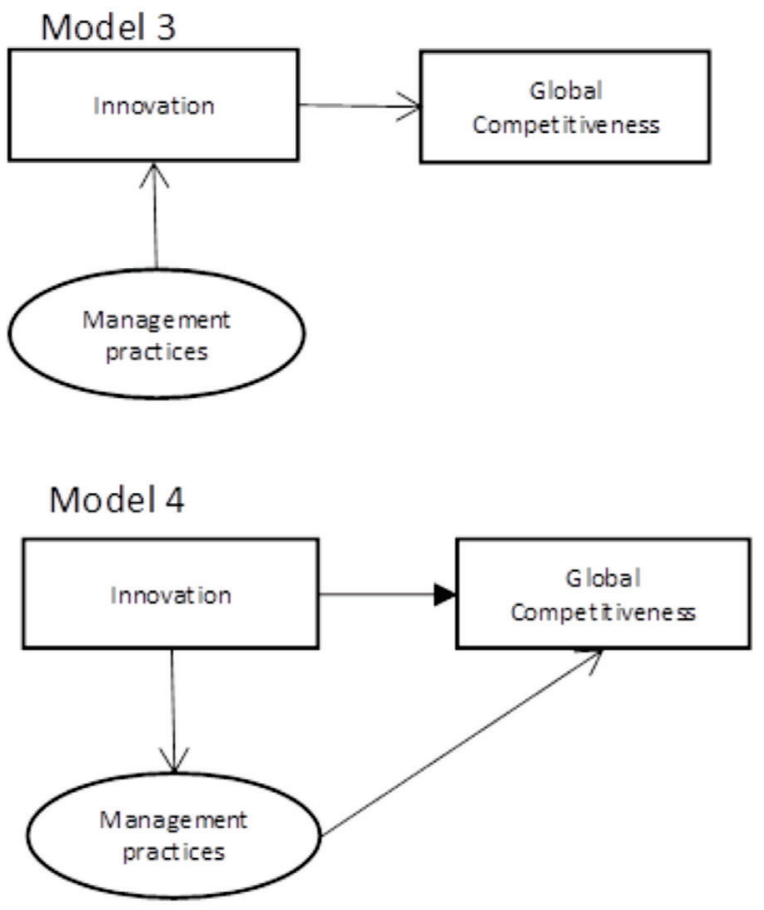

\section{Model 5}

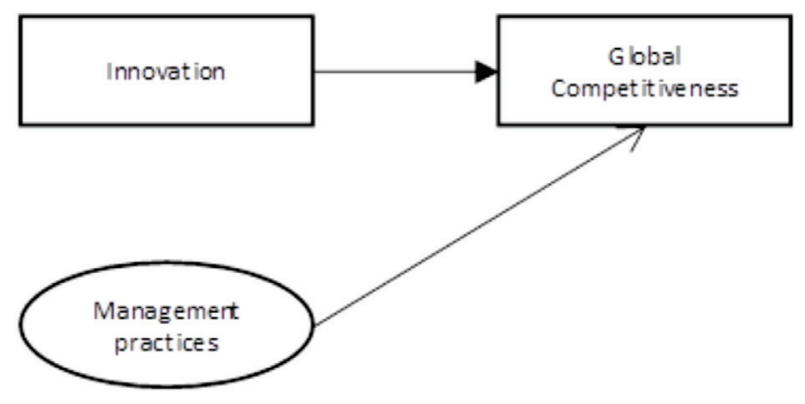

Figure 2 - Theoretical models developed Source: Authors

The quantitative method used involved confirmatory factor analysis and structural equation modeling (Rivera, Jacomossi, Barrichello, \& Morano, 2018), and all the calculations were performed using the IBM SPSS Amos ${ }^{\oplus} 22.0$ software. 


\section{Presentation, Analysis, and Discussion of the Results}

In the factor analysis, the estimate of the measurement model involving the Management Practices variable was performed by using the maximum likelihood method (Byrne, 2010; Marôco, 2014).

In terms of the normality of this same variable, studies show that even data without a normal distribution can be acceptable as long as skewness (Sk) and univariate kurtosis $(\mathrm{Ku})$ measurements for each item are close to zero and the absolute values are not greater than 2 and 7, respectively (Marôco, 2014). The results of the univariate normality tests performed for the skewness ([0.038:0.958]) and kurtosis ([0.046:0.931]) parameters indicate that none of the variables presented $|S k|>2$ and $|\mathrm{Ku}|>7$, and therefore there was no extreme violation of normality.
The measurement model (Figure 3), after the evaluation of normality assumptions, presented healthy goodness of fit indices (Byrne, 2010; Marôco, 2014), namely: $\chi^{2}=89,797_{(42)}$, $\mathrm{p}<0.001, \mathrm{NFI}=0.954, \mathrm{RFI}=0.928, \mathrm{IFI}=0.975$, $\mathrm{CFI}=0.975$, RMSEA $=0.091$.

Considering that the RMSEA value was close to the maximum acceptable (0.10 Marôco, 2014), two actions were taken: 1) the Mahalanobis distance test (Byrne, 2010) was performed to verify the presence of outliers; 2) the Hiring and firing variable, which presented a low factor loading (Table 3), was suppressed. Both actions did not substantially alter the value of the index, thus it was decided not to make any change in relation to the initial plan.

The correlations found between the items of the latent variable were incorporated into the model, improving its fit, and did not compromise the analyses performed (Byrne, 2010).

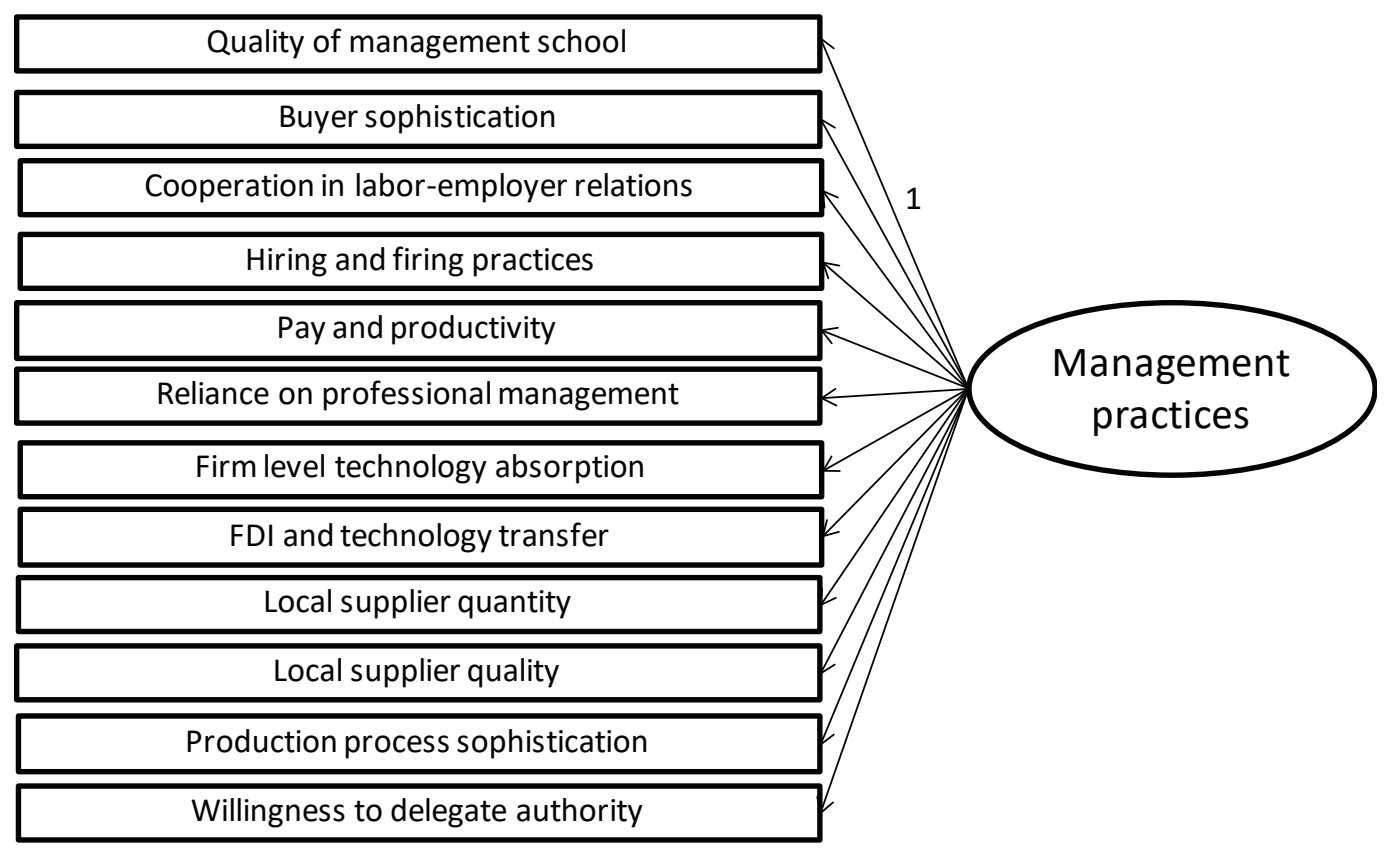

Figure 3 - Measurement model

Source: Authors

The evaluation of the measurement model was also performed using the factor loading of each item within the Management Practices variable (factor validity), average variance extracted (AVE - convergent validity), and composite reliability (CR), as can be seen in Table 3. 
Table 3

\section{Confirmatory factor analysis}

\begin{tabular}{|c|c|c|c|c|}
\hline Variable & Item & Factorial load & AVE & CR \\
\hline \multirow{12}{*}{$\begin{array}{l}\text { Management } \\
\text { practices }\end{array}$} & Quality of management schools & 0.849 & 0.680 & 0.961 \\
\hline & Buyer sophistication & 0.834 & & \\
\hline & Cooperation in labor employer relations & 0.730 & & \\
\hline & Hiring and firing practices & 0.393 & & \\
\hline & Pay and productivity & 0.850 & & \\
\hline & Reliance on professional management & 0.907 & & \\
\hline & Firm level technology absorption & 0.946 & & \\
\hline & FDI and technology transfer & 0.821 & & \\
\hline & Local supplier quantity & 0.687 & & \\
\hline & Local supplier quality & 0.919 & & \\
\hline & Production process sophistication & 0.947 & & \\
\hline & Willingness to delegate authority & 0.851 & & \\
\hline
\end{tabular}

Source: Authors

The average variance extracted (AVE) and composite reliability (CR) values were both higher than the minimum recommended, which are, respectively, $\geq 0.5$ and $\geq 0.7$ (Byrne, 2010; Marôco, 2014).

The items that make up the Management Practices variable meet the requirements of factor validity, composite reliability, and convergent validity (Byrne, 2010; Marôco, 2014), making them valid for the study carried out.

The effect of common method variance was also tested for the Management Practices variable by using the partial correlation approach, a method recommended by Lindell and Whitney (2001), which has been utilized in studies such as those developed by Jarvenpaa and Majchrzak (2008) and those mentioned by Richardson, Simmering, and Sturman (2009). In the present study, this approach indicated that there is no common method variance effect.

Following the findings of the confirmatory factor analysis, theoretical models proposed based on the literature review were analyzed. For Model 1, which deals with the relationship between Innovation and Global Competitiveness, a positive and significant relationship was found from the first to the second variable, which was tested to evaluate the quality of the data used, given that this is a relationship that has been confirmed in the literature (Nelson \& Winter, 1982; Pavitt, 1984; Porter, 1990; Rosenberg, 1982; Schumpeter, 1934). The standardized path coefficient $(\beta=0.851, \mathrm{p}<0.001)$ and the coefficient of determination $(\mathrm{R} 2=0.724)$ obtained demonstrate this alignment, corroborating the findings of the field literature.

Model 2 presented healthy goodness of fit indices $\left(\chi^{2}=131.975(53), \mathrm{p}<0.001\right.$, $\mathrm{NFI}=0.943, \mathrm{RFI}=0.916, \mathrm{IFI}=0.965, \mathrm{CFI}$ $=0.965$, RMSEA $=0.104)$ (Byrne, 2010; Marôco, 2014). The standardized path coefficient $(\beta=0.959, p<0.001)$ and the coefficient of determination $(\mathrm{R} 2=0.919)$ corroborate Bloom and Van Reenen $(2006,2007,2010)$ in terms of the relationship from best management practices to global competitiveness and, as in Model 1, ensure the quality of the data used.

As for the measurement model, the RMSEA value was slightly above the maximum acceptable (0.10 - Marôco, 2014). Due to this, two actions were taken: 1) the Mahalanobis distance test (Byrne, 2010) was performed; 2) the Hiring and firing variable was suppressed. Both actions did not substantially alter the value of the 
index, thus it was decided not to make any change in relation to the initial plan.

With this accomplished, Models 3, 4, and 5 were analyzed and compared with the objective of verifying their goodness of fit levels. It was found that Model 5 did not present good indices $\left(\chi^{2}=384.287_{(65)}, \mathrm{p}<0.001, \mathrm{NFI}=0.850\right.$, $\mathrm{RFI}=0.790, \mathrm{IFI}=0.872, \mathrm{CFI}=0.870, \mathrm{RMSEA}$ = 0.189) (Byrne, 2010; Marôco, 2014), which led to its being discarded from further analyses. Models 3 and 4 presented healthy goodness of fit indices (Byrne, 2010; Marôco, 2014) and their respective values can be found in Table 4 .

Table 4

\section{Fit indicators}

\begin{tabular}{lcc}
\hline Index & Model 3 & Model 4 \\
\hline$\chi^{2}$ & 281.065 & 153.756 \\
$\mathrm{df}$ & 65 & 64 \\
$\Delta \chi^{2 \mathrm{i}}$ & - & 127.309 \\
$\Delta \mathrm{df}^{\mathrm{i}}$ & - & 1 \\
$\chi_{\text {critico }}^{2}{ }^{*} \mathrm{i}^{\mathrm{i}}$ & - & 3.84 \\
NFI & 0.890 & 0.940 \\
RFI & 0.846 & 0.914 \\
IFI & 0.913 & 0.964 \\
CFI & 0.912 & 0.964 \\
RMSEA & 0.156 & 0.101 \\
\hline
\end{tabular}

** $\mathrm{p}<0,05$ i: Differences measured related to model 3 Source: Authors

Comparing Model 3 and Model 4, the latter has a value of $\Delta \chi_{(1)}^{2}=127.309>\chi_{\text {(critical) }}^{2}=$ $3.84(\mathrm{p}<0.05)$, which indicates that the models are statistically different, with Model 4 providing a better explanation of the phenomenon due to the lower absolute value of $\chi^{2}$, indicating that this is the closest to the estimated theoretical model (Marôco, 2014). Thus, it was verified that Model 4 provides the best explanation of the relationship between the three variables in this study.

Table 5 shows that the relationship between Innovation and Global Competitiveness loses significance in the presence of the Management Practices variable, given that Model 4 presents this variable as a mediator in the relationship between Innovation and Global Competitiveness. This means that the relationship between Innovation and Global Competitiveness is important; however, it is positively influenced by the existence of Best Management Practices.

Table 5

\section{Path coefficients and coefficients of determination $\left(\mathbf{R}^{2}\right)$}

\begin{tabular}{lc}
\hline Path coefficients & Model $\mathbf{4}$ \\
\hline Innovation $\rightarrow$ Global Competitiveness & -0.161 \\
Management Practices $\rightarrow$ Global & $1.106^{* * *}$ \\
Competitiveness & \\
Innovation $\rightarrow$ Management Practices & $0.915^{* * *}$ \\
\hline Coefficients of determination $\left(\mathbf{R}^{2}\right)$ & Model 4 \\
\hline Management Practices & 0.837 \\
Global Competitiveness & 0.923 \\
${ }^{* * *} \mathrm{p}<0.001$ & \\
Source: Authors &
\end{tabular}

Coefficients of determination $\left(\mathrm{R}^{2}\right)$ convey the capacity that independent variables have to explain the dependent variables. In the present case, it can be concluded that Global Competitiveness is highly explained by Innovation when there is a path through Management Practices. Given this, it is observed that both coefficients of determination (explanatory power for the dependent variables) are high enough to reinforce the mediation phenomenon.

Vieira (2009) defines a mediator variable as one that, when present in a structural model, diminishes the magnitude of the relationship between an antecedent variable and a consequent variable. Therefore, a variable can be considered a mediator when it influences the relationship between antecedent and consequent variables, to the extent that its insertion in the model neutralizes or even reduces the force of the direct relationship between these variables.

According to Baron and Kenny (1986), a step by step path analysis procedure should be applied to verify the existence of mediation, which was performed according to the following conditions: 
- The antecedent variable significantly affects the mediator variable: in Model 4, the path coefficient from Innovation to Management Practices is equal to 0.915 and is significant;

- The antecedent variable significantly affects the consequent variable in the absence of the mediator variable: in Model 1, the path coefficient from Innovation to Global Competitiveness, in the absence of Management Practices, is equal to 0.851 and is significant;

- The mediator variable has a significant effect on the consequent variable: in Model 4, the path coefficient from Management Practices to Global Competitiveness is equal to 1.106 and is significant. Since the value obtained was greater than 1 , tests were performed to discard the possibility of multicollinearity, which validated the findings (Jöreskog, 1999);

- The effect of the antecedent variable on the consequent variable weakens in the presence of the mediator variable: in Model 4, the path coefficient from Innovation to Global Competitiveness in the presence of Management Practices is equal to -0.161 , which is negative and not significant.

In Model 4, Management Practices meets all the requirements for mediation (Baron \& Kenny, 1986; Iacobucci, Saldanha, \& Deng, 2007), which indicates that this model is the most appropriate representation of the relationship between Best Management Practices, Innovation, and Global Competitiveness. This being so, it is verified that innovation is not the only explanation for a nation's increase in global competitiveness. The management element is a variable that helps explain why certain companies obtain better results in comparison to others. Given that companies are situated in certain territories, this also explains the economic predominance of some countries in relation to others, corroborating the findings of Porter (1990), who says that countries are powerful due to the companies that are headquartered there.

The existence of best management practices means that innovation ceases to exert a direct influence on global competitiveness, and management in turn absorbs all its impact on global competitiveness. In other words, it has been observed that innovation is not enough by itself to affect global competitiveness, to the extent that it needs best management practices to ensure this impact, which means that the effectiveness of innovation in the market is only realized through management, thus corroborating Markides and Anderson (2006) and Schumpeter (1934). Therefore, it is evident that it is not enough to analyze the relationship between innovation and global competitiveness without considering the presence of best management practices.

\section{Conclusions}

This study sought to measure whether the relationship between innovation and global competitiveness is influenced by the simultaneous existence of best management practices. To do this, structural equation modeling and the Global Competitiveness Report (GCR) 2016-2017 (Schwab et al., 2016) were used. Even though the GCR does not deal directly with best management practices, this article used several of its indicators to construct a variable that measures this effect.

Some studies treat the relationship between innovation and global competitiveness as a direct one, which has been confirmed in the field literature (Nelson \& Winter, 1982; Pavitt, 1984; Porter, 1990; Rosenberg, 1982; Schumpeter, 1934). However, the present research found that the importance of best management practices cannot be ignored within the context of innovation and the competitiveness of companies and nations. It is clear that this variable acts as a mediator in the existing relationship between innovation and global competitiveness. This means that global competitiveness cannot be analyzed solely in terms of innovation or solely in terms of management, because the model 
presented in this study demonstrates that there is a complementary relationship between these variables. This contributes to filling the theoretical gap presented since this research showed the role of best management practices as a mediating factor between innovation and global competitiveness.

The important academic contribution of this study is that it demonstrates that innovation alone cannot ensure competitiveness and requires the simultaneous presence of best management practices. This does not mean that there is no direct relationship between innovation and global competitiveness. It just demonstrates that innovation needs to be accompanied by best management practices. Thus, this research reveals the importance of working with this variable when devising public policies in order to increase the competitiveness of companies and, consequently, as proposed by Porter (1990), of the nations in which they are operating.

Bloom and Van Reenen (2006, 2007, 2010) already demonstrated the influence of best management practices in this relationship but did not study the relationship between best management practices, innovation, and global competitiveness together. This study, based on structural equation modeling, quantitatively demonstrates the mediating role of best management practices and how they can influence the relationship between innovation and global competitiveness, thus offering greater explanatory power in terms of the relationship between the variables, and thereby demonstrating this important idea statistically.

In terms of corporate contributions, this study shows that some of the constituent items of the management practices variable can and should be implemented and improved by company administrations to improve the mediation between innovation and global competitiveness. These elements thus turn innovation into a competitive advantage if it is accompanied by best management practices.

The development of the best management practices variable included various indicators from the GCR and may not contain all the aspects that it characterizes, which represents an opportunity for future studies to broaden the discussion of this topic.

\section{Acknowledgements}

We thank the National Council for Scientific and Technological Development (CNPq - Project no. 152128/2016-6) for its support of this work.

\section{References}

Abramovitz, M. (1950). Inventories and business cycles. New York: National Bureau of Economic Research.

Agarwal, R., Brown, P. J., Green, R., Randhawa, K., \& Tan, H. (2014). Management practices of Australian manufacturing firms: why are some firms more innovative? International Journal of Production Research, 52(21), 6496-6517. https:// doi.org/10.1080/00207543.2014.949362

Alexopoulos, M., \& Tombe, T. (2009). Management matters (No. 12). Toronto.

Aoki, R. (1991). R\&D competition for product innovation: An endless race. The American Economic Review, 81(2), 252-256.

Armstrong, C. E., \& Lengnick-Hall, C. A. (2013). The Pandora's box of social integration mechanisms. Journal of Strategy and Management, 6(1), 4-26. https://doi.org/10.1108/17554251311296530

Bae, C. (2016). R\&D Spillovers with Endogenous Absorptive Capacity: Lessons for Developing Countries. East Asian Economic Review (EAER), 20(2), 191-228. https://doi.org/10.2139/ ssrn. 2804910

Baron, R. M., \& Kenny, D. A. (1986). The moderator-mediator variable distinction in social psychological research: Conceptual, strategic, and statistical considerations. Journal of Personality and Social Psychology, 51(6), 1173-1182.

Bentler, P. M., \& Chou, C. (1987). Practical issues in structural modeling. Sociological 
Methods \& Research, 16(1), 78-117. https://doi. org/10.1177/0049124187016001004

Bertrand, O., \& Mol, M. J. (2013). The antecedents and innovation effects of domestic and offshore R\&D outsourcing: The contingent impact of cognitive distance and absorptive capacity. Strategic Management Journal, 34(6), 751-760. https://doi.org/10.1002/smj.2034

Blomstrom, M. (1986). Foreign Investment and Productive Efficiency: The Case of Mexico. The Journal of Industrial Economics, 35(1), 97-110. https://doi.org/10.2307/2098609

Blomstrom, M., \& Kokko, A. (1998). Multinational Corporations and Spillovers. Journal of Economic Surveys, 12(3), 247-277. https://doi.org/10.1111/1467-6419.00056

Bloom, N., \& Van Reenen, J. (2006). Measuring and Explaining Management Practices Across Firms and Countries. London.

Bloom, N., \& Van Reenen, J. (2007). Measuring and Explaining Management Practices Across Firms and Countries. The Quarterly Journal of Economics, 122(4), 1351-1408. https://doi. org/10.1162/qjec.2007.122.4.1351

Bloom, N., \& Van Reenen, J. (2010). Why Do Management Practices Differ across Firms and Countries? The Journal of Economic Perspectives, 24(1), 203-224.

Brettel, M., Greve, G. I., \& Flatten, T. C. (2011). Giving up Linearity: Absorptive Capacity and Performance. Journal of Managerial Issues, 223(2), 164-189.

Byrne, B. M. (2010). Structural Equation Modeling with AMOS: basic concepts, applications, and programming (2nd ed.). New York: Routledge.

Carvalho, L., \& Avellar, A. P. (2013). Inovação e Produtividade: Evidências Empíricas para Empresas Brasileiras. In $41^{\circ}$ Encontro Nacional de Economia-ANPEC. Foz do Iguacú.
Cavalcante, L. R., \& de Negri, F. (2014). Produtividade no Brasil: Uma análise do período recente. Brasília: Instituto de Pesquisa Econômica Aplicada (IPEA).

Chatzoglou, P., \& Chatzoudes, D. (2017). The role of innovation in building competitive advantages: an empirical investigation. European Journal of Innovation Management. https://doi. org/10.1108/EJIM-02-2017-0015

Christensen, C. M. (2006). The Ongoing Process of Building a Theory of Disruption. Journal of Product and Innovation Management, 23(1), 39-55.

Christensen, C. M., \& Raynor, M. E. (2013). Creating and Sustaining Successful Growth. Boston, MA: Harvard Business School Press.

Cohen, W. M., \& Levinthal, D. A. (1990). Absorptive-Capacity - A new Perspective on Learning and Innovation. Administrative Science Quarterly, 35(1), 128-152. https://doi. org/10.2307/2393553

Crossan, M. M., \& Apaydin, M. (2010). A Multi-Dimensional Framework of Organizational Innovation: A Systematic Review of the Literature. Journal of Management Studies, 47(6), 1154-1191. https://doi.org/10.1111/j.14676486.2009.00880.x

Cua, K. O., Mckone, K. E., \& Schroeder, R. G. (2001). Relationships between implementation of TQM , JIT , and TPM and manufacturing performance. Journal of Operations Management, 19(6), 675-694. https://doi.org/10.1016/S02726963(01)00066-3

De Cerio, J. M. (2003). Quality management practices and operational performance: Empirical evidence for Spanish industry. International Journal of Production Research, 41(12), 2763-2786. https://doi.org/10.1080/0020754031000093150

Drejer, A. (2002). Situations for innovation management: towards a contingency 
model. European Journal of Innovation Management, 5(1), 4-17. https://doi. org/10.1108/14601060210415135

Dutta, S., Lanvin, B., \& Wunsch-Vincent, S. (2016). The Global Innovation Index 2016. Stronger Innovation Linkages for. Geneva: World Intellectual Property Organization. https://doi. org/978-2-9522210-8-5

Feldmann, P. R. (2014). Management in Latin America. New York: Springer. https://doi. org/10.1007/978-3-319-04750-8

Goedhuys, M. (2007). The impact of innovation activities on productivity and firm growth: Evidence from Brazil (No. 2007-02). Maastricht.

Gordon, R. J. (2016). The rise and fall of American growth : the U.S. standard of living since the Civil War. Oxford: Princeton University Press.

Greve, H. R. (2003). A Behavioral Theory of R\&D Expenditures and Innovations: Evidence from Shipbuilding. Academy of Management Journal, 46(6), 685-702. https://doi. org/10.5465/30040661

Griliches, Z. (1979). Issues in Assessing the Contribution of Research and Development to Productivity Growth. The Bell Journal of Economics, 10(1), 92-116. https://doi.org/10.2307/3003321

Hsu, C.-C., Tan, K. C., Kannan, V. R., \& Leong, G. K. (2009). Supply chain management practices as a mediator of the relationship between operations capability and firm performance. International Journal of Production Research, 47(3), 835-855. https://doi.org/10.1080/00207540701452142

Iacobucci, D., Saldanha, N., \& Deng, X. (2007). A mediation on mediation: Evidence that structural equation models perform better than regression. Journal of Consumer Psychological, 7(2), 140-154. https://doi.org/10.1016/S10577408(07)70020-7

Ichijo, K., \& Nonaka, I. (2007). Knowledge Creation and Management: New Challenges for
Managers. (K. Ichijo \& I. Nonaka, Eds.). New York: Oxford University Press.

Jarvenpaa, S. L., \& Majchrzak, A. (2008). Knowledge Collaboration Among Professionals Protecting National Security: Role of Transactive Memories in Ego-Centered Knowledge Networks. Organization Science, 19(2), 260-276. https://doi. org/10.1287/orsc. 1070.0315

Jöreskog, K. G. (1999). How large can a standardized coefficient be? No, 22-24.

Khan, F., Salim, R., Bloch, H., \& Islam, N. (2017). The public R\&D and productivity growth in Australia's broadacre agriculture: is there a link? Australian Journal of Agricultural and Resource Economics, 61(2), 285-303. https://doi. org/10.1111/1467-8489.12202

Kim, M. (2015). Productivity spillovers from FDI and the role of domestic firm's absorptive capacity in South Korean manufacturing industries. Empirical Economics, 48(2), 807-827. https:// doi.org/10.1007/s00181-014-0804-z

Lederman, D., Messina, J., Pienknagura, S., \& Rigolini, J. (2014). Latin American Entrepreneurs: Many Firms but Little Innovation. Washington DC: The World Bank. https://doi.org/10.1596/978-14648-0012-2

Lerner, J., \& Azoulay, P. (2012). Technological Innovation and organizations. In R. Gibbons \& J. Roberts (Eds.), Handbook of Organizational Economics (pp. 575-603). Princeton: Princeton University Press.

Lindell, M. K., \& Whitney, D. J. (2001). Accounting for Common Method Variance in Cross-Selectional Research Designs. Journal of Applied Psychology, 86(1), 114-121. https://doi. org/10.1037//0021-9010.86.1.114

Liu, Z. (2008). Foreign direct investment and technology spillovers: Theory and evidence. Journal of Development Economics, 85(1-2), 176-193. https://doi.org/10.1016/j.jdeveco.2006.07.001 
Mairesse, J., \& Robin, S. (2009). Innovation and productivity: a firm-level analysis for French Manufacturing and Services using CIS3 and CIS4 data. In Conference in Honour of Prof. David Encaoua. Paris: Paris School of Economics.

Markides, C. C., \& Anderson, J. (2006). Creativity is not enough: ICT-enabled strategic innovation. European Journal of Innovation Management, 9(2), 129-148. https://doi. org/10.1108/14601060610663532

Marôco, J. (2014). Análise de Equaçôes Estruturais: Fundamentos teóricos, software e aplicaçóes (2nd ed.). Pêro Pinheiro: ReportNumber.

Mazzucato, M. (2015). The entrepreneurial state : debunking public vs. private sector myths. London: Anthem Press.

Medda, G., \& Piga, C. A. (2014). Technological spillovers and productivity in Italian manufacturing firms. Journal of Productivity Analysis, 41(3), 419-434. https://doi.org/10.1007/s11123-0130351-1

Mundlak, Y. (1961). Empirical Production Function Free of Management Bias. Journal of Farm Economics, 43(1), 44-56. https://doi. org/10.2307/1235460

Nagano, M. S., Stefanovitz, J. P., \& Vick, T. E. (2014). Characterization of Brazilian Industrial Companies' Processes and Challenges as to Innovation Management. Revista Brasileira de Gestão de Negócios, 16(51), 163-179. https://doi. org/10.7819/rbgn.v16i51.1426

Najafi-Tavani, S., Sharifi, H., \& S. Ismail, H. (2014). A study of contingency relationships between supplier involvement, absorptive capacity and agile product innovation. International Journal of Operations \& Production Management, 34(1), 65-92. https://doi.org/10.1108/ IJOPM-09-2011-0331

Nelson, R. R., \& Winter, S. G. (1982). An Evolutionary Theory of Economic Change.
Cambridge: The Belknap Press of Harvard University Press.

Panayides, P. (2006). Enhancing innovation capability through relationship management and implications for performance. European Journal of Innovation Management, 9(4), 466-483. https:// doi.org/10.1108/14601060610707876

Parisi, M. L., Schiantarelli, F., \& Sembenelli, A. (2006). Productivity, innovation and R\&D: Micro evidence for Italy. European Economic Review, 50(8), 2037-2061. https://doi.org/10.1016/j. euroecorev.2005.08.002

Pavitt, K. (1984). Sectoral patterns of technical change: Towards a taxonomy and a theory. Research Policy, 13(6), 343-373.

Porter, M. (1990). The Competitive Advantage of Nations. New York: Free Press.

Rao, S. S., Solis, L. L. E., \& Raghunathan, T. S. (1999). A framework for international quality management research: development and validation of a measurement instrument. Total Quality Management, 10(7), 1047-1075.

Richardson, H. A., Simmering, M. J., \& Sturman, M. C. (2009). A Tale of Three Perspectives: Examining Post Hoc Statistical Techniques for Detection and Corrections of Common Method Variance. Organizational Methods, 12(4), 762-200. https://doi.org/10.1177/1094428109332834.

Ritala, P., \& Hurmelinna-Laukkanen, P. (2013). Incremental and Radical Innovation in Coopetition-The Role of Absorptive Capacity and Appropriability. Journal of Product Innovation Management, 30(1), 154-169. https://doi. org/10.1111/j.1540-5885.2012.00956.x

Rivera, J. R. D., Jacomossi, R. R., Barrichello, A., \& Morano, R. S. (2018). Using structural equation modeling: patterns and trends of publications in Brazilian journals. Revista de 
Gestão, 25(3), 291-302. https://doi.org/10.1108/ REGE-05-2018-036

Rogers, M. (2006). R\&D and Productivity in the UK: evidence from firm-level data in the 1990 s (No. 255). Oxford.

Rosenberg, N. (1982). Inside the Black Box: Technology and Economics. Cambridge (UK): Cambridge University Press.

Sadikoglu, E., \& Zehir, C. (2010). Investigating the effects of innovation and employee performance on the relationship between total quality management practices and firm performance: An empirical study of Turkish firms. International Journal of Production Economics, 127(1), 13-26.

Schumpeter, J. A. (1934). The theory of economic development: An inquiry into profits, capital, credit, interest, and the business cycle. Cambridge: Harvard University Press.

Schwab, K., Sala-i-Martín, X., Samans, R., \& Blanke, J. (2016). The Global Competitiveness Report 2016 - 2017. Geneva: World Economic Forum. https://doi.org/92-95044-35-5

Solow, R. M. (1956). A Contribution to the Theory of Economic Growth. The Quarterly Journal of Economics, 70(1), 65-94. https://doi. org/10.2307/1884513

Steingraber, R. (2009). Inovação e produtividade: o papel dos sistemas de inovação para a indústria brasileira. Universidade Federal do Paraná.

Suyanto, Bloch, H., \& Salim, R. A. (2012). Foreign Direct Investment Spillovers and Productivity Growth in Indonesian Garment and Electronics Manufacturing. The Journal of Development Studies, 48(10), 1397-1411. https:// doi.org/10.1080/00220388.2011.646992

Suyanto, \& Salim, R. (2013). Foreign direct investment spillovers and technical efficiency in the Indonesian pharmaceutical sector: firm level evidence. Applied Economics, 45(3), 383-395. https://doi.org/10.1080/00036846.2011.605554

Teixeira, A. A. C., \& dos Santos, L. C. B. (2016). Desempenho de inovação nas empresas de serviços e KIBS vis à vis indústria transformadora: A relevância da capacidade de absorção e da abertura. Revista Brasileira de Gestão de Negocios, 18(59), 43-66. https://doi.org/10.7819/rbgn. v18i59.2215

Vieira, V. A. (2009). Moderação, mediação, moderadora-mediadora e efeitos indiretos em modelagem de equaçóes estruturais: uma aplicação no modelo de desconfirmação de expectativas. Revista de Administração Universidade de São Paulo RAUSP, 44(1), 17-33.

Wakelin, K. (2001). Productivity growth and R\&D expenditure in UK manufacturing firms (No. Research Paper 2000/20). Nottingham.

Zahra, S. A., \& George, G. (2002). Absorptive Capacity: A Review, Reconceptualization, and Extension. Academy of Management Review, 27(2), 165-203.

Zhang, R., Sun, K., Delgado, M., Kumbhakar, S., Delgado, M. S., \& Kumbhakar, S. C. (2011). Productivity in China's high technology industry: Regional heterogeneity and R\&D. Technological Forecasting and Social Change, 79(1), 127-141. 
Agências de Fomento:

Conselho Nacional de Desenvolvimento Científico e Tecnológico - CNPQ

\section{About the Authors:}

1. Paulo Roberto Feldmann, Doctor of Business Administration - Universidade de Sáo Paulo - Programa de Pós-Graduação em Administração / Faculdade de Economia, Administração e Contabilidade - São Paulo - Brazil. E-mail: feldmann@usp.br

\section{ORCIID}

(iD) 0000-0001-5662-8735

2. Rafael Ricardo Jacomossi, Doctor of Business Administration - Centro Universitário FEI - São Paulo Brazil. E-mail: rjacomossi@fei.edu.br

\section{ORCIID}

(iD) 0000-0001-5584-142X

3. Alcides Barrichello - Doctor of Business Administration - Universidade Presbiteriana Mackenzie Centro de Ciências Sociais e Aplicadas - São Paulo - Brazil. E-mail: alcidesbarrichel@uol.com.br

ORCIID

(iD) 0000-0003-1531-3651

4. Rogério Scabim Morano - Doctor of Business Administration - Universidade Federal de São Paulo Departamento de Engenharia Química - Diadema - Brazil. E-mail: r.morano@uol.com.br

ORCIID

(iD) 0000-0002-3233-0843

\section{Contribution of each author}

\begin{tabular}{|c|c|c|c|c|}
\hline Contribution & $\begin{array}{l}\text { Paulo Roberto } \\
\text { Feldmann }\end{array}$ & $\begin{array}{c}\text { Rafael } \\
\text { Ricardo } \\
\text { Jacomossi }\end{array}$ & $\begin{array}{c}\text { Alcides } \\
\text { Barrichello }\end{array}$ & $\begin{array}{l}\text { Rogério } \\
\text { Scabim } \\
\text { Morano }\end{array}$ \\
\hline 1. Definition of research problem & $\sqrt{ }$ & $\sqrt{ }$ & $\sqrt{ }$ & $\sqrt{ }$ \\
\hline $\begin{array}{l}\text { 2. Development of hypotheses or research questions (empirical } \\
\text { studies) }\end{array}$ & $\sqrt{ }$ & $\sqrt{ }$ & $\sqrt{ }$ & $\sqrt{ }$ \\
\hline 3. Development of theoretical propositions (theoretical work) & $\sqrt{ }$ & $\sqrt{ }$ & $\sqrt{ }$ & $\sqrt{ }$ \\
\hline 4. Theoretical foundation/Literature review & $\sqrt{ }$ & $\sqrt{ }$ & $\sqrt{ }$ & $\sqrt{ }$ \\
\hline 5. Definition of methodological procedures & $\sqrt{ }$ & $\sqrt{ }$ & $\sqrt{ }$ & $\sqrt{ }$ \\
\hline 6. Data collection & $\sqrt{ }$ & $\sqrt{ }$ & $\sqrt{ }$ & $\sqrt{ }$ \\
\hline 7. Statistical analysis & $\sqrt{ }$ & $\sqrt{ }$ & $\sqrt{ }$ & $\sqrt{ }$ \\
\hline 8. Analysis and interpretation of data & $\sqrt{ }$ & $\sqrt{ }$ & $\sqrt{ }$ & $\sqrt{ }$ \\
\hline 9. Critical revision of the manuscript & $\sqrt{ }$ & $\sqrt{ }$ & $\sqrt{ }$ & $\sqrt{ }$ \\
\hline 10. Manuscript writing & $\sqrt{ }$ & $\sqrt{ }$ & $\sqrt{ }$ & $\sqrt{ }$ \\
\hline 11. Other (please specify which) & & & & \\
\hline
\end{tabular}

